\title{
DEVELOPMENT OF KEY COMPETENCIES OF PUPILS TECHNICAL VOCATIONAL EDUCATION
}

\section{Jana JUHÁSOVÁ}

\begin{abstract}
The aim of this paper is to point out the possibility of the development of key competencies in the teaching of technical vocational education. By development of key competencies we contribute to lifelong learning, the process of constant change and the amount of the further development in our society.
\end{abstract}

Key words: key competencies, students, teaching method

Abstratkt: Ciel'om príspevku je poukázat' na možnosti rozvoja klúčových kompetencií vo vyučovaní technických

odborov vzdelávania. Dôležité je poukázat' na výber vhodných aktivizujúcich metód vo výučbe a tým aj zlepšit' vývoj jednotlivých kompetencií. Príspevok poukazuje na to, aké aktivizujúce metódy sme zvolili vo výskumnej časti dizertačnej práce a zároveň uvádzame výsledky práce. Rozvojom klúčových kompetencií prispievame $\mathrm{k}$ celoživotnému vzdelávaniu, $\mathrm{k}$ procesu stálych zmien a množstvu d’alšieho rozvoja nás v spoločnosti.

Klúúová slova: klúčové kompetencie, študenti, vyučovací metódy

\section{Introduction}

Recently, the center of attention is the issue of educational science core competencies, which is related to increase the effectiveness of teaching. Caught the essence of the wisdom of the old Latin (Seneca the Younger) "Non scholae, sed vitae discimus" - "Not for school but for life we learn". For the first time in our educational programs emerging requirements for pupils' learning outcomes, which are not based on the specifics of individual subjects, but the concern is more universal knowledge, abilities, skills and attitudes which normally need in their lives and are useful in many life and work situations. These are identified as core competencies. (Milenium 2001)

Work in our lives in the scale of values occupies a prominent place. Is an important factor to ensure the material life and is also a source of social contacts with a number of interviews, meeting people, of establishing friendships.

By Siergrist, if a person loses his job involuntarily, it is associated with far-reaching consequences: the person feels like a single isolated from society. Unemployment has great social and political impact. Resigned frustration and subsequent job loss is large and operates various forms of the immediate surroundings. With long-term unemployment leads to mental and psychosomatic diseases and also profound changes in social life. There was also a significant personality change, thereby gets to the loss of personal status. One of the motives behind the development of his personality is developing key competences, such as the example. Self -learning, to give the unemployed a new impetus to independent and responsible learning. This leads him to independence is the ability to give people guidance and lead them to the next step to getting a job. Key competences represent further education, to which, however, each of us come independent work and initiative. What we are interested in a greater amount of core competencies, the more it pushes us to develop their own personalities. Lead us to lifelong learning and the process of constant change and the amount of the further development of our society. This can reduce the already existing unemployment and adapt to the requirements of a potential employer. Receive useful skills that can be used to find new jobs.

The process of self-learning and selfeducation will is up to each of us, we cannot rely on the fact that somebody poured knowledge in the head, but rather their own learning process has to be on his own responsibility and every one of us. Based on self-learning is also contributing to adapt to 
situations rapidly changing framework conditions encountered in everyday life. It is up to us how they can adapt as they can handle and making them not considered obstacles.

A more thorough analysis of the issue in the available literature study showed that it is not possible within the scope of this work to carry out in-depth analysis of each individual key competencies individual separately. An important part is, if we focus on their overall development in the learning process. The ability to sell is\&quot; one of the fundamental skills in characterizing his personality when applying for a job on which candidate apparent ability to communicate effectively. (Albert)

\section{Methods of research}

In our experiment we used 4 research methods:

\section{Pedagogical experiment}

The aim of the teaching experiment was to evaluate the impact of education using methods for activating students' knowledge. The experiment was conducted under natural conditions Secondary Technical School in the subject of the Transport Road transport. The survey sample was selected based on availability. Experimental elements represented activating methods used in teaching thematic units Technical - economic indicators, monitoring and evaluation operations of road transport social legislation on drivers' work. To time - thematic program we have implemented the following methods: Brainstorming, Case Studies, Project teaching Problem teaching, and Didactic game. Experimental teaching took place in the range of 13 weeks and 39 lessons for each group. 16 teaching hours were devoted to thematic units: Technical - economic indicators. 10 lessons were devoted to thematic units: Monitoring and evaluating the operation of road transport and 12 lessons were dedicated thematic units: Social legislation for drivers' work. 1 lesson focused on repeat all thematic units before output achievement test.

For the purpose of the experiment, we created a control and experimental group. In the experiment in the experimental group (EG) we implemented using activating teaching methods in the control group (CG), we carried out without the use of activating methods.

2. Didactic tests
Didactic test was designed to detect and verify the knowledge acquired by us designed teaching methods in the experimental and comparison of knowledge achieved by pupils in the control group. Didactic test consisted of questions directed to the use of knowledge and then proposing solutions to the situation. Questions were directed to find out how students can use knowledge of typical and problematic situations.

\section{Questionnaire method}

It is designed for mass production of data, for subsequent statistical processing. Thus we capture the views of pupils and their attitudes to learning, to working methods, their interests, satisfaction with the proposed method of teaching us. We have used an open and closed question. Questionnaires were used to evaluate statistical hypotheses.

4. Statistical methods for processing data obtained

a) Statistical Descriptions: a statistical description of the results of research, reducing the large amount of collected data into clear and understandable form, tabulation and graphical display of results of research

b) Statistical inference: finding degree of generalization of research findings, testing (verification) hypotheses

The statistical hypothesis is a statement about the probability distribution of one or number of random variables. When deciding on the validity of the hypothesis can be put differently stringent criteria for this research are adopting a significance level of 0.05 , so the probability of error of $5 \%$. Statements, which are based on $95 \%$ statistical confidence, we call significant it is statistically significant.

\section{F-test}

F-test is a test that is used to test the statistical hypotheses. In practical terms, we can conclude that its use is linked with the term "dispersion (variation)" F-test - test the correlation of two variances In this test, if it is not rejected the null hypothesis (H0), ie variances of the two files are identical, then continue testing the conformance tests of the two middle values of independent sets in a homogeneous variance (t-test) When this test is rejected the null hypothesis (H0) and accept the alternative hypothesis (H1), ie variances of the two sets are not identical, then continue 
testing the conformance tests of mean values of two independent sets in non-homogeneous variance (t-test).

\section{Chi-square test goodness of fit}

Pearson's Chi-square test of goodness of fit statistical test of the null hypothesis, which argues that the frequency in each category is equal to the expected (theoretical) frequency.

If the $\mathrm{P}$-value is less than the chosen significance level (traditionally $5 \%=0.05$ ), the null hypothesis is rejected. This means that the difference between the frequency detected in the sample and the expected frequency is too great for it to be merely the result of random selection, that is statistically significant.

If the $\mathrm{P}$ - value is equal to or greater than the chosen significance level, the null hypothesis can not be rejected. This means that the difference between the frequency detected in the sample and the expected multiplicity may be due to random sampling, that is not statistically significant. (Chraska)

\section{Cochrane- Cox test}

Cochrane $\mathrm{Q}$ test is used in a number of samples of a binary dependent variable. Tests whether dependent samples are statistically significantly different diameters binary variable (ie shares, percentages). Cochrane Q test is essentially an alternative to one-way analysis of variance for repeated measurements of the binary dependent variable. The test can be used to test changes in the holdings at different time points in the same sample. $\mathrm{Q}$ test is typically used to compare the complexity of the questions of the questionnaire, which can be answered either right or wrong.

\section{Research hypotheses}

Basic hypothesis: H: The proposed experimental system of teaching Vocational Course Road transport, focused on the development of key competences by introducing activating methods, our experiment will be more effective than traditional instruction. Efficiency in this case, we will understand better the results achieved in achievement test and significantly positive pupil attitudes expressed in the questionnaire. For a successful verification of the hypotheses were verified experimentally following working hypothesis: H1: Among the output achievement test results of students in the experimental group and the results of students in the control group is significant difference

H2: Between the responses of students output didactic questionnaire concerning the difficulty of mastering the subject in the experimental group and the responses of students in the control group is significant difference

H3: Between the responses of students output didactic questionnaire concerning the evaluation of teaching syllabus Road transport in the experimental group and the responses of students in the control group is significant difference H4: By using methods of activating the output responses of students didactic questionnaire concerning attitudes to improve the instruction of road transport in the experimental group and the responses of students in the control group is significant difference

\section{Research objective}

Main objective: Compare didactic force development of key competencies by introducing activating methods with traditional teaching. To fulfill the main objectives have been formulated following intermediate targets:

1) Find out what teaching methods are most suitable for the development of key competencies. Implement the teaching of subjects appropriate methods to increase the effectiveness of teaching

2) Identify the level of student satisfaction with teaching and realized its subsequent evaluation

3) Find the didactic effectiveness of activating methods to develop core competencies and compare it with the effect of traditional didactic teaching.

4) Statistical analysis and evaluation of results

5) Propose recommendations for further enhancement of teaching subjects where students can develop core competencies in other subjects

\section{Methods for developing competence in teaching}

Selection of appropriate methods is the efficiency of the teaching process essential. Generally there are two methods of teaching: 
1) a method, the essence of which is the transfer of finished knowledge

2) the method by which students acquire new knowledge and acquire various skills of their active involvement. (Orbanova)

Factors that influence teachers in choosing instructional methods include the following:

- teaching content

- learning objectives

- own teaching style

Teaching Methods:

brainstorming

case studies

project learning

problem teaching

didactic game

Teaching methods constitute the learning process is very important element. By using these pupils conveys relevant curriculum content.

Contemporary modern times require that within the teaching process used not only conventional teaching methods such as lecture and reading, as well as non-traditional methods, which can mobilize students to work independently when seeking appropriate solutions to problems. We also support the development of logical, analytical and creative thinking.

\section{Design of experiment}

\section{Monitoring and evaluation of road transport operation}

Teacher divides students into threemember groups. Groups should be equivalent to the number of students as well as knowledge. The role of a teacher during the didactic games will generally monitor compliance with the rules and possibly guided by the course of the game. The evaluation will consist in scoring when getting the best grades. Teacher assigns a task:

Record of vehicle operation write out data:

Name of the driver:

date of performance:

fuel:

place of loading:

place of discharge:

initial state tachograph:

fulltime tachograph:

No. Record of vehicle operation:

registration number of such vehicles:

type of motor vehicle
Driving, loading and transport capacity Teacher explains the basic concepts of the curriculum pupils interpretative form, explains the meaning and use of indicators in the business of freight and passenger traffic, which makes use of examples, illustrations. Will use the help and students will expect the feedback. It is used the form storytelling, demonstrations solving tasks where students will interact. The teacher divides students into 5-6 member teams. The number of students has to be equal in each group as well as knowledge. The role of a teacher during the didactic games will generally monitor compliance with the rules and possibly guided by the course of the game. The evaluation will consist in getting the best result.

The teacher prepares cards. Half of them give different terms relating to the technicaleconomic indicators (driving, loading and transport capacity), on the other half writes the corresponding definition of a unit in which they are expressed. Divide the students into groups. Each group has its own set of cards. After the game, each student based on their cards verifies the knowledge of other students in the group while they control each other.

\section{Results of research}

The main objective of the research was to compare the effectiveness of didactic development of key competencies by introducing activating and traditional teaching methods. To fulfill the main goal, we have formulated the milestones where our task was to seek the views of students and teachers to use appropriate teaching methods preferring to work independently and mutual development of core competencies in the subject of Road transport. Based on the sub-targets we have set the main hypothesis and the resulting working hypothesis. These we statistically evaluated and the results confirmed that the introduction of activating methods in teaching learning is more effective than traditional teaching. Efficiency in this case, we understand better the results achieved in a significant achievement test positive student's attitudes expressed in the questionnaire. Designed an experimental system of teaching vocational syllabus Road transport was more effective than traditional teaching even confirmed after 
statistical processing of the results of hypotheses.

Table No.1 Verification of hypothesis

\begin{tabular}{|l|l|l|}
\hline Hypothesis & $\begin{array}{l}\text { Verification and evaluation of } \\
\text { hypothesis }\end{array}$ & Result \\
\hline \hline H1 & $\begin{array}{l}\text { Fisher- Snedecor F-test } \\
\text { F=2,7599 } \\
\text { F Crit }=1,921=>\mathrm{F}>\mathrm{F} \text { crit }=\text { Thus, the } \\
\text { scattering } \\
\text { is a statistically significant difference }\end{array}$ & Confirmed \\
\hline \hline H2 & $\begin{array}{l}\text { Personas chi-square, } \chi^{2}=15.81 \\
\text { Resulting value of the test criteria } \chi^{2} \\
=15.81 \text { compared } \\
\text { with the critical value } \chi^{2} \mathrm{KR}= \\
9.4877 \\
\text { which applies } \chi^{2}>\chi^{2} \mathrm{KR}\end{array}$ & Confirmed \\
\hline $\mathbf{H 3}$ & $\begin{array}{l}\text { Personas chi-square, } \chi^{2}=35.81, \chi^{2} \\
\text { KR }=9.4877 \\
\text { which applies } \chi^{2}>\chi^{2} \mathrm{KR}\end{array}$ & Confirmed \\
\hline
\end{tabular}

\section{Recommendation for pedagogies and} pedagogical practice

Recommendation for pedagogies:

1.carry out further research to develop key competences

2.oriented teaching in all subjects on the development of key competencies

3.suggest learning with the application activating methods for each subject and placed on the website where the information is not accessible only to teachers but also for parents of students

4.optimize courses based on the requirements of the labor market

5.organize education staff in the application of activating methods in teaching

6.support new research projects in Slovakia, which will help develop key competences of pupils

\section{Recommendations for teaching practice}

1. improved material support teaching in secondary schools so as to be able to use activating methods in teaching

2. enable pupils to frequent Working in groups, solve problem tasks and be able to self-assessment lesson

3. wherever possible to apply more practical than theoretical teaching

4. more often involved in the organization of student teaching hours through presentations or to give him the opportunity to judge another classmate

5. propose published on the website of the school discussion forum where teachers will share experiences and suggestions for the application of activating teaching methods

6. monitor students during class performance in a role that teacher enters. This is especially useful for work involving practical work, which can be physical observation

\section{The contribution of teaching experience}

1.making teaching materials used in the experimental study at the school website 2.the possibility of using the proposed teaching not only the subject of road transport, but also in other subjects 3.research confirmed that achieved efficiency measured knowledge and attitudes while teaching the subject to be improved by introducing activating methods in teaching

\section{Conclusion}

The aim of the thesis was to compare the effectiveness of didactic development of key competencies by introducing activating and traditional teaching methods. The results of empirical research aimed at developing key competencies of students in technical fields of education confirmed that the experimental group students demonstrated not only improved knowledge and attitudes to teaching the subject, but the final interview, we found that the methods applied teaching would like to welcome in other subjects. We have set the main hypothesis according to which we prepared the initial questionnaire. The selection of the sample consisted of Secondary School 4th grade students of transport and we taught the subject specialist road transport. Before the teaching we needed to check pupil's knowledge and consequently pupils divided into experimental and control groups. This division was preceded by the results of the entrance achievement test. According to the prescribed curriculum and teaching methods prepared by us, we carried out in the experimental group teaching itself. At each lesson in the experimental group, we used at least one activating methods. In contrast, in the control group are taught in the traditional way. The results of the opinions, attitudes exit questionnaire mastering the curriculum was easier for them and more interesting. Based on the research results we can confirm the effectiveness of the instruction, which was 
Výzkumný článek

confirmed by better results pupil. Pupil's progress is reflected in the development of its core competencies, which results in targeted training for their progressive development. With this work we want to highlight the importance of using activating methods in teaching that contribute to the development of key competences of pupils and teachers at the same time. Solution, results and recommendations were presented at national and international conferences. We hope that the presented results contribute to deeper insights into research problems, create space for an informed debate and will open up a new perspective on improving the development of core competencies in teaching.

\section{References:}

[1] ALBERT, A. 2002. Rozvoj kvality v škole. Bratislava : Metodicko-pedagogické centrum, 2002. ISBN 80-8052-166-2.
[2] BELZ, H., SIEGRIST, M. Klíčové kompetence a jejich rozvijení. Praha : Portál, 2001. s. 376. ISBN 80-7178-479-6.

[3] CHRÁSKA, M.: Metody pedagogického výzkumu. Praha: Grada Publishing a.s., 2007. 265 s. ISBN 978-80-247-1369-4

[4] ORBÁNOVÁ, D.: Didaktika podnikovej ekonomiky. Bratislava: Ekonóm, 2005

[5] MILÉNIUM: Národný program výchovy a vzdelávania v Slovenskej republike na najbližšich 15 až 20 rokov. MŠ Bratislava: IRIS, 2002. ISBN 80-89018-36-X.Education Policy Analysis: Edition. Paris: OECD, 2001.

Ing. Jana Juhásová, lectured: doc. PaedDr. Danka Lukáčová, PhD

Katedra technickej a informačnej technológie

Pedagogická fakulta UKF Nitra

Dražovská cesta 4 , Nitra

E-mail: jana.kapralova@gmail.com 